\title{
Top Management Team Attraction As A Strategic Asset: A Longitudinal Simulation Test Of The Resource Based View
}

Michael D. Michalisin, (E-mail: drmike@cba.siu.edu), Southern Illinois University at Carbondale Steven J. Karau, (E-mail: skarau@cba.siu.edu), Southern Illinois University at Carbondale Edward Conrad, (E-mail: edconrad@cba.siu.edu), Southern Illinois University at Carbondale

\begin{abstract}
The Resource Based View's (RBV) main prescription is that strategic assets are sustainable sources of superior industry returns. In the current research, we examined the ability of top management team attraction (TMTA) to operate as a strategic asset and produce sustainable competitive advantage. We used a longitudinal study of 83 simulation teams functioning as top management teams of competing airlines to demonstrate that top management team attraction was positively associated with superior returns, and that this relationship increased over time. Our study benefits both theorists and managers. The key implication for theorists is that TMTA can positively impact firm performance over time, thereby providing strong support for the RBV. The key implication for managers is that taking steps to enhance TMTA and team dynamics can create competitive advantage for their firms.
\end{abstract}

\section{INTRODUCTION}

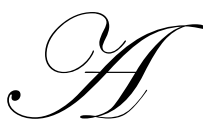

ccording to the Resource Based View of the Firm (RBV), resources and capabilities are the main drivers of sustainable competitive advantage, particularly those that are simultaneously valuable, rare, difficult and costly to imitate, and nonsubstitutable (Barney, 1991), called strategic assets (Amit \& Schoemaker, 1993). Since its inception (Wernerfelt, 1984), RBV has received considerable attention in the strategy literature (Mauri \& Micheals, 1998). Unfortunately, empirical testing of RBV is still in the developmental stages.

This study tests RBV's main prescription using a strategic management simulation involving 83 teams of senior-level undergraduate business students functioning as top management teams of competing airline companies, to examine the degree to which top management team attraction can develop into a sustainable resource that produces superior industry returns. We chose to use a simulation methodology to allow us to study phenomena central to the RBV in a well-controlled fashion over time. Although using a student sample raises external validity concerns, we felt that this concern was outweighed by the ability to employ a well-controlled experimental methodology. Specifically, we were able to assess team attraction using a well-validated instrument and assess its impact on firm performance over time in a tightly-controlled fashion. Thus, we were able to measure an intangible strategic asset with a level of control and precision that would be difficult or impossible to obtain from intact top management teams.

We selected top management team attraction (i.e., the level of top management team members' attraction to their team) as our major predictor variable for four reasons. First, team attraction appears to simultaneously possess all of the characteristics of a strategic asset. Second, team attraction is a variable that exists in the top management teams of firms across many industries, and that changes over time. Third, little research has examined the relationship between team attraction and firm performance. Fifth, organizations often invest in initiatives to enhance management 
cohesion in hopes of increasing team attraction. Therefore, it is important to determine whether these investments are well spent.

This study makes four important contributions. First, this study examines a socially complex, intangible resource that appears to meet RBV's criteria for being a strategic asset, thereby providing a good test of RBV's main prescription. Second, although a good deal of research has been conducted on concepts related to team attractionsuch as team cohesion - only a minority of that work has examined intact work teams, and very few studies of cohesion have examined its implications for firm performance. Indeed, no studies have directly examined the link between top management team attraction and firm performance. In addition, our use of a longitudinal simulation allows us to examine how the relationship between team attraction and firm performance develops and changes over time.

\section{Resource Based View of the Firm}

According to the RBV, resources are the main determinant of firm performance, based on the assumptions that firms are unique bundles of resources and that resources are relatively immobile, in part due to imperfectly competitive resource factor markets (Amit \& Schoemaker, 1993; Barney, 1986, 1991; Peteraf, 1993; Wernerfelt, 1984). Barney (1991) defines resources as "all assets, capabilities, organizational processes, firm attributes, information, knowledge, etc. controlled by a firm that enable a firm to conceive of and implement strategies that improve its efficiency and effectiveness" (p 101). Capabilities and processes are included in the definition because they are merely sets of resources used to perform integrated tasks (Amit \& Schoemaker, 1993). In other words, resources are single assets (e.g., a firm's reputation) or bundles of assets (e.g., a firm's information system) that develop over time and can bestow probable future economics benefits to the firm (Collis \& Montgomery, 1997).

Strategic assets are resources that are simultaneously valuable, rare, difficult or costly to imitate, and nonsubstitutable. A resource is valuable when it allows the firm to exploit opportunities in the market or to thwart competitive threats. Valuable resources that are not rare, called pedestrian resources, are only sources of competitive parity and not sustainable sources of superior returns. Resources that are valuable and rare are potential sources of competitive advantage, unless competitors find strategically equivalent substitute resources (Barney \& McEwing, 1996). Resource based advantages are also temporary if competitors can imitate them at a reasonable cost. Socially complex resources are difficult to imitate because they are a function of the personalities and relationships among firm employees.

RBV scholars are recognizing that strategic assets are generally not tangible in nature (Godfrey \& Hill, 1995; Michalisin, Smith, \& Kline 1997). Tangible resources, such as property, plant, equipment, and physical technologies, are often purchasable in the marketplace and thus are not rare. Internally developed technologies can be valuable resources, but become obsolete in highly innovative markets and can be re-engineered by competitors. Thus, the intangible resource, rather than its mere physical manifestations, constitutes the strategic asset. Intangible resources are not directly observable and are difficult to imitate.

A number of studies have documented that a wide variety of intangible resources (such as managerial experience, technological expertise, reputation, and employee relationships) can serve as strategic resources capable of enhancing a variety of firm performance outcomes. Other studies provide evidence that CEOs may represent strategic assets due to their potential ability to impact firm performance. Table 1 presents a representative overview of prior RBV research conducted at the business, corporate, and CEO units of analysis. All of these studies support RBV's main premise and key assumptions, constituting an important step in testing the validity of RBV. Another crucial step in testing RBV is to test its main prescription - that strategic assets are the drivers of superior industry returns. Unfortunately, research on RBV's main prescription is still in the developmental stages. 


\section{Top Management Team Attraction}

A top management team (TMT) is a group of high-level managers responsible for formulating and implementing the firm's strategies (Hambrick \& Mason, 1984). The power to control the direction and performance of the firm probably makes the TMT the most important and influential team in the firm (Smith et al.,1994; Wernerfelt, 1989). Thus, RBV logic indicates that key intangible TMT resources can be strategic assets to the firm (Carpenter et al., 2001).

One key intangible TMT resource that may serve as a strategic asset is the level of top management team members' attraction to their team. We define TMT attraction as the degree to which TMT members desire to identify with and be accepted members of the TMT. Research studying a variety of group types has shown that members' levels of attraction to their groups contribute to a host of positive outcomes, including steady contributions, productivity, and effectiveness (Hogg, 1992). However, nearly all of the prior research on attraction to group has examined non-organizational teams. In the current research, we studied teams in an organizational and strategic context. We conclude from the logic of prior research on other types of groups that members of TMTs who have a strong attraction to their team are likely to make regular and valuable contributions that are likely to have strategic value for their firms.

Team attraction is a specific element of the broader and more diffuse concept of team cohesion. Cohesion is a complex, possibly multidimensional construct that has been defined and operationalized in a variety of ways (Tziner, 1982). Festinger's classic definition treated cohesion as the "resultant of all forces acting on the member to remain in the group" (1950, p.274). These 'forces' include a range of factors such as member attraction, shared goals, network benefits, and social identification with the group. Among these forces, attraction has been most heavily emphasized in the cohesion literature (Hogg, 1992; Lott \& Lott, 1965). For this reason, we focus on team attraction in the current research.

A large number of studies have shown that cohesion is often positively associated with team performance, especially when the team adopts norms of high productivity (Beal, Cohen, Burke, \& McLendon, 2003; Hogg, 1992; Mullen \& Copper, 1994). However, the vast majority of studies in the large cohesion literature have examined nonorganizational groups, and organizational studies of cohesion have focused on groups and teams at the functional or task level, rather than at the TMT level. To our knowledge, only three studies have examined TMT cohesion, and no studies have directly examined team attraction. Specifically, Michel and Hambrick (1992), Michalisin, Karau, and Tangpong (2004), and by Smith et al. (1994) all found positive relationships between TMT cohesion and firm performance. Although these studies help establish the importance of cohesion in organizations, measurement concerns limit the confidence with which strong conclusions can be drawn. Specifically, Michel and Hambrick (1992) did not actually measure cohesion, but instead used team tenure as a proxy for it. Similarly, Smith et al.(1994) studied cohesion using a measure of social integration that assessed multiple aspects of group performance, including elements extending beyond the core of cohesion, such as the uniformity of team decisions and the avoidance of competition within the TMT. Finally, Michalisin et al. (2004) used a measure f cohesion that assessed a variety of group perceptions such as liking, enjoyment, perceptions of working well together, efficient time usage, and trusting teammates to work hard. Thus, it clearly included some aspects of group process that may not always be central to cohesion.

Our current research makes three distinct contributions over prior work: (a) we examine team attraction as a core component of cohesion in a manner that is not confounded with other group process variables, (b) we use a wellvalidated measure of team attraction that has been shown to have good validity, reliability, and internal consistency, and (c) we conduct time-series analyses to speak more directly to how the relationship between team attraction and firm performance unfolds over time.

With regard to the RBV, the level of top management team attraction (TMTA) appears to simultaneously possess all of the characteristics of a strategic asset. First, team attraction has been found to relate to a variety of favorable group processes and enhanced performance (Hogg, 1992). Hence, it is likely to be a valuable asset for TMTs as well. TMTA is also rare, and difficult and costly to imitate because (a) TMTA varies across companies 
based on the unique composition of each TMT, (b) TMTA changes over time and is affected by interaction and unique historical conditions, making it rare and difficult to imitate, (c) TMTA is a socially complex phenomenon reflecting the unique personalities of team members (Hambrick, 1995), (d) TMTA is an invisible resource, making it hard for competitors to imitate, (e) the impact of TMTA on firm performance is likely causally ambiguous, and (f) attempting to perfectly replicate another firm's TMTA would probably require hiring their entire TMT, which would be costly and risky given that TMTA could change as a function of the new corporate climate.

TMTA is also imperfectly substitutable. Because team attraction is an evolving social dynamic that emerges as a function of shared experiences over time, it would be practically impossible to provide a perfect substitute for team attraction without creating these same shared experiences. In sum, TMTA appears to possess all of the attributes of a strategic asset, and thus, according to RBV, should be positively related to firm returns that are superior to the industry median.

Hypothesis 1: Top management team attraction will be positively associated with superior industry returns.

Our use of multiple measurement periods also allowed us to assess whether the relationship between TMTA and firm performance varied over time. We reasoned that it may take some time for team attraction to translate into superior returns due to the complex nature of managing a simulated firm. Time may be required for teams to identify member expertise and understand the market environment sufficiently to allow the advantages of team attraction to result in superior returns. Hence, the relationship between TMTA and superior industry returns should strengthen over time.

Hypothesis 2: The positive relationship between top management team attraction and superior industry returns will strengthen over time.

\section{METHOD}

\section{Participants}

Participants were 453 undergraduate management students (225 men, 128 women; 430 native U.S. students, 23 international students) enrolled in 9 sections ( 3 fall semester sections and 6 spring semester sections) of the capstone Strategic Management and Policy course for graduating seniors at a Doctoral/Research Extensive University. We created diverse teams by categorizing individuals in terms of major, gender, and nationality and randomly assigning individuals to teams within each category in a stepwise fashion so that each team included a variety of majors, included no more than one international student, and included both men and women. This process resulted in the creation of 83 diverse teams.

\section{Strategic Management Simulation}

Recent years have seen increased use of complex management simulations as a valuable empirical tool (e.g., Chatman \& Barsade, 1995; Keys \& Wolfe, 1990; Nees, 1983; Schwenk, 1982). We chose simulation as our research method because it allowed us to study complex phenomena in a controlled setting that incorporated a host of company and industry factors commonly faced by TMTs. Our use of a simulation methodology adds additional breadth to the literature, which has relied mostly on anecdotal evidence, cross-sectional studies, archival studies of financial reports, and case analysis.

We used Airline, A Strategic Management Simulation (Smith \& Golden, 2002). Airline is a complex, computer-assisted simulation in which teams function as TMT's of individual airlines that compete against one another in the commuter airline industry. The simulation was designed to model many key attributes of management decisions and resultant firm outcomes and produce rich financial feedback to participants about both their own firm and the industry. The simulation is also rather unique in that the simulation algorithms are based on extensive research of the commuter airline industry, thereby providing as high a level of realism in the market dynamics of the simulation as possible. 
Each section represented a single industry comprised of 4-12 firms. Although sections varied in the number of competing airlines, all firms had an equal chance to attain profitability because the simulation adjusted the number of available markets to each airline based on the number of firms in the industry. At the beginning of the first simulation session (75 minutes) individuals were assigned to teams, become acquainted with their teammates, and started discussing the simulation. Teams then met weekly in separate 75-minute sessions across an eleven-week period to make all strategic decisions about their business. Each simulation period (i.e., week) represented a calendar quarter for the firm.

Experienced graduate teaching assistants keyed the decision form information into the computer's simulation software each week, which computed a myriad of team and industry information. At the beginning of each simulation period, each team received printouts of their financial statements, operations management statistics, financial statistics, market reports, industry statistics, and so on. Each graduate assistant received training on how to run the software and manage the simulation classes to promote consistency. We periodically attended each section to ensure consistency. Fifteen percent of each student's grade was based on their airline's financial performance relative to competitors. This was determined using a number of financial ratios, including those used to measure the dependent variables.

\section{MEASUREMENT}

\section{Measurement of Superior Industry Returns}

RBV's main prescription indicates that strategic assets are the key source of competitive advantage and superior industry returns. We used a composite of four relative performance measures to measure superior industry returns (i.e., firm performance): Return On Sales (ROS), Earnings Per Share (EPS), Net Profit per Seat Mile (NPSM), and Net Profit Per Employee (NPEE). Because strategic management is concerned with the performance of a firm relative to its industry competitors, all four performance measures were calculated as relative median scores. Relative median performance represents the difference between the firm's performance and the industry median. For instance, relative median ROS is the difference between the firm's ROS and industry median ROS, indicating whether the firm's ROS was above (superior), at (median), or below (inferior) industry ROS (and to what extent). After Principal Component Analyses (PCA) showed that these four relative performance measures were highly correlated and loaded onto a single component (see Table 2), they were combined into a single component measure of superior industry returns. These techniques efficiently control for industry effects and permit triangulation across multiple performance measures.

\section{Measurement of Top Management Team Attraction}

At the beginning of the first simulation class, participants were assigned to teams and instructed to use the class time to get to know each other and to begin talking about the simulation. At the end of the class period, participants were asked to complete the Group Attitude Scale (GAS, Evans \& Jarvis, 1986). The 20-item GAS was designed to measure one's attraction to a group. Across several validation studies, Evans and Jarvis (1986) found that the GAS has good reliability and excellent internal consistency (alphas ranging from .90 to .96 across studies and assessment times). It has been used in more than 20 studies examining a wide variety of groups in laboratory, field, organizational, and therapy settings.

\section{Measurement of Control Variables}

\section{Prior performance}

Consistent with the strategy literature, we controlled for the impact of prior performance on current performance. This control allowed us to evaluate the relationship between team attraction and current firm performance, in the presence of past performance, thereby removing prior performance as a confounding factor in any team attraction-performance relationships that emerge. 


\section{Leverage}

Companies with high debt levels use large portions of their cash flows to service debt obligations, thus reducing free cash flow. A reduction in free cash flow disciplines managers to invest wisely (Jansen, 1986) and closely monitor strategy (Hoskisson, Johnson, \& Moeser, 1994). Hence, leveraging debt can improve performance unless too much debt is used to fund assets and is unable to meet debt obligations. In this study, leverage was measured using the firm's debt to equity ratio.

\section{Firm Size}

Firm size can impact performance through economies of scale, monopoly power and bargaining power (Chandler, 1990). In this study, firm size was measured as total airplane seats (in the fleet) to capture both the number and the size of planes.

\section{Competitors}

Each section of the course represented one industry containing 4-12 airline companies, depending on the number of students in the section. Porter (1980) tells us that the number of competitors in an industry can affect rivalry, as well as industry attractiveness ands profitability. Thus, we included a control variable that represented the number of competitors in the industry.

\section{TMT Size and Semester}

Because the size of teams ranged from three to five members depending on enrollment in each section, we included a control variable for TMT size. Because there were three Fall and six Spring sections, we also included a dummy variable to control for any effect due to semester.

\section{RESULTS}

We tested our hypotheses using repeated measures Analysis of Covariance (ANCOVA), contrast analysis, and cross-sectional multiple regression equations (Ordinary Least Squares). Specifically, we used repeated measures ANCOVA to determine if team attraction was positively related with firm performance, as we predicted in Hypothesis 1. Then we conducted repeated-measures contrasts to assess the specific nature of the statistical relationship (e.g., linear, quadradic, cubic) between team attraction and firm performance over time, as well as cross-sectional regression models to further clarify the specific pattern of relationships. In short, our analysis strategy allowed us to assess both when team attraction became positively associated with firm performance and how this relationship changed over time.

Principal component analysis (PCA) of the four firm performance measures showed significant BTC chi squares $(\mathrm{p}<.001)$ for all eleven periods (see Table 2$)$. The firm performance measures were highly correlated and loaded onto a single component for all survey periods. Thus, we used the resulting PCA scores as a composite measure of firm performance based on superior industry returns (SIR).

We show the correlations and descriptive statistics for period 11 in Table 3. Team attraction had a positive, highly significant relationship with SIR $(\mathrm{p}<0.05)$, supporting Hypothesis 1 . Prior performance $(\mathrm{p}<0.01)$ and size $(\mathrm{p}<0.05)$ had a significant positive relationship with SIR, while leverage $(\mathrm{p}<0.01)$ had a statistically significant negative relationship with SIR. Some of the control and independent variables had statistically significant relationships, but the variance inflation factors did not indicate multicollinearity. Other statistical and graphical analyses did not show any violations of the assumptions underlying the multiple regression and ANCOVA analyses.

We conducted a repeated-measures ANCOVA with SIR as the dependent variable measured across 11 time periods. There was a significant positive effect of TMT attraction on SIR, lending strong support to Hypothesis $1, F$ $(10,760)=3.51, p<.001$. Contrast analysis helped to clarify further the nature of this relationship. Specifically, there was a strong, significant linear relationship between team attraction and firm performance, such that the strength of 
the relationship between TMT attraction and firm performance increased over time, $F(1,76)=8.64, p<.001$. This pattern is shown in Figure 1. This lends strong support to Hypothesis 2.

To provide additional information about the relationships between our key study variables at each simulation period, we also conducted a series of multiple regression analyses. We show the results in Table 4. TMT attraction was not significantly associated with firm performance in periods 1 through 5 , but then had a positive, statistically significant relationship in periods 6 through 11, with the strongest relationship at period 6 . These results show that it took time for TMT attraction to produce superior industry returns, but that once this relationship was established it remained robust across the rest of the simulation. These results lend support to Hypothesis 2. Among the control variables, prior performance had a positive, significant relationship with SIR in periods 3 through 11. Other control variables were significant at various points in time. $R^{2}$ for the regression model was highly significant in every period.

\section{DISCUSSION}

Our results strongly suggest that attraction to one's team constitutes a strategic asset in TMTs. Team attraction had a strong, significant, positive relationship with firm performance as measured by superior industry returns. The emergence of this relationship, even in the presence of powerful control variables, such as prior firm performance, suggests that it can be a fairly potent strategic asset. Our inclusion of prior performance as a control also helps establish that team attraction is enhancing performance, and not the other way around. We also found a significant linear increase in the strength of the relationship between TMT attraction and firm performance over time, suggesting that team attraction may be an asset that needs to be developed over time. However, the amount of SIR that TMTA is capable of generating may have a ceiling such that once a fairly high level of firm performance has been attained, addition gains via TMTA alone are unlikely. Additional performance beyond this level may require the deployment of additional strategic assets. These results represent one of a very limited number of empirical demonstrations that RBV's main proposition may well have merit, and that intangible factors that are not directly linked to physical assets may have serious potential as viable strategic assets.

Our study also helps unravel what specific elements of cohesion have strategic value for TMTs. Namely, the limited number of prior studies on cohesion and firm performance have either studied cohesion indirectly using proxies such as team tenure, or used fairly general measures of cohesion that are likely to reflect multiple group processes. Our results demonstrate that team attraction, distinct from other elements of cohesion or group process, has firm performance implications.

Our study makes additional theoretical and practical contributions. For theorists, we combined the logic embodied in the RBV literature with relevant behavioral research to systematically illustrate that TMT attraction is simultaneously valuable, rare, difficult and costly to imitate, and nonsubstitutable. Our empirical results corroborate those of existing RBV studies in lending support for RBV's main prescription, as well as for contemporary thinking that strategic assets are intangible in nature.

Our study also has practical implications. Most important, our results suggest that team attraction is an intangible strategic asset that can produce sustained competitive advantage. Thus, our research raises the possibility that factors that can increase TMT members' attraction to the team may well produce sustainable competitive advantage for the firm. If these findings replicate across samples and industries, it is possible that the careful use of team-building exercises, establishment of shared goals or values, and careful selection of TMT members for compatibility, may increase the strategic value of the TMT. More generally, our results suggest that intangible assets that have been traditionally disregarded may indeed be important competitive levers. Our results also suggest that initiatives designed to increase TMT attraction may not produce immediate positive impact, but that the relationship may develop over time.

Although this study makes a number of important contributions, it also has some limitations. External validity is an issue because we studied a sample of students playing the role of TMTs. This gave us a great deal of control over variables and allows us to speak more directly to causality, but may limit our ability to generalize. Our sample was also restricted to one university, and the simulation was based on only one industry. Yet, despite these considerations, there are several reasons why our study may still have some external validity. First, the simulation was 
modeled after actual industry variables, simulated random change, and incorporated a host of major decisions found in intact organizations. Second, TMTs made their own decisions, and resulting firm and industry outcomes were reliant on the interaction of the decision outcomes of multiple firms. Third, the simulation created a high degree of involvement, thereby enhancing the likelihood that basic processes were indeed activated. Finally, using a simulation allowed us to examine the performance of a large number of firms in multiple markets, a strategy that would be difficult and costly to pursue les within intact top management teams. Thus, our simulation teams had a number of attributes in common with work place teams in terms of shared goals, a common outcome, interaction and decision making processes that unfold over time, consideration of strategic issues relevant to the firm in relation to feedback, and competition with other firms. Nevertheless, readers should recognize that the consequences associated with firm decisions are more substantial to practicing managers than they were to our simulated TMTs, and our simulation teams did not experience the same levels of pressure and accountability that most practicing TMTs experience. Hence, research that examines TMT attraction in actual organizations is an important future step.

In our research we have taken the vital first step of demonstrating that differences in TMTA across teams have a significant impact on sustained competitiveness. However, we did not seek to determine exactly how TMTA enhances performance, nor did we seek to identify which specific processes and mechanisms were primary over others. The dynamics of TMTA-firm performance relationships are likely to involve more variables than we were able to include in our simulation, and a number of moderating variables may influence TMTA-firm performance relationships. For example, TMTA may have more influence on firm performance when corporate cultures are consultative, decision making is participative rather than autocratic, key knowledge is distributed across multiple TMT members, and creativity is central to industry performance. Temporal issues are also important to interpreting our results. A major asset of the simulation was the ability to study firm and industry dynamics in a controlled fashion over time. However, the 11 quarters were simulated across an 11-week period only. It would be interesting to examine the effects of TMTA over longer time periods.

Finally, in order to fully exploit the implications of the RBV, future research should examine the strategic effects of other potential intangible assets such as team member personality or TMT culture. Given that our study suggests that TMT attraction is a viable source of competitive advantage, it seems likely that other intangible assets may have similar strategic value. We hope that the current study will be useful in generating additional research on the RBV and its applicability to firm performance, as well as in highlighting the potential usefulness of complex business simulations for studying strategic management issues.

\section{REFERENCES}

1. Amit, R. \& Schoemaker, P. J. H. (1993). Strategic assets and organizational rent. Strategic Management Journal, 14, 33-46.

2. Barney, J. B. (1991). Organizational culture: Can it be a source of sustainable competitive advantage? Academy of Management Review, 11, 656-665.

3. Barney, J. B. \& McEwing, M. D. (1996). Gaining and sustaining competitive advantage. Boston: AddisonWesley.

4. Beal, D. J., Cohen, R. R., Burke, M. J., \& McLendon, C. L. (2003). Cohesion and performance in groups: A meta-analytic clarification of construct relations. Journal of Applied Psychology, 88, 989-1004.

5. Bergh, D. D. (1998). Product-market uncertainty, portfolio restructuring, and performance: An informationprocessing and resource-based view. Journal of Management, 24, 135-155.

6. Berman, S. L., Down, J., \& Hill, C. W. L. (2002). Tacit knowledge as a source of competitive advantage in the National Basketball Association. Academy of Management Journal, 45, 13-31.

7. Brush, T. H. \& Artz, K. W. (1999). Toward a contingent resource-based theory: The impact of information asymmetry on the value of capabilities in veterinary medicine. Strategic Management Journal, 20, 223-250.

8. Carpenter, M. A., Sanders, W. G., \& Gregersen, H. B. (2001). Bundling human capital with organizational context: The impact of international assignment experience on multinational firm experience and CEO pay. Academy of Management Journal, 44, 493-511.

9. Chandler, A. D. (1990). Scale and scope. Cambridge, MA, Harvard University Press.

10. Chatman J. A. \& Barsade, S. G. (1995). Personality, organizational culture, and cooperation: Evidence from a business simulation. Administrative Science Quarterly, 40, 423-443. 
11. Christmann, P. (2000). Effects of "best practices" of environmental management on cost advantage: The role of complementary assets. Academy of Management Journal, 43, 663-680.

12. Collis, D. J. (1991). A resource based analysis of global competition: The case of the bearings industry. Strategic Management Journal, 12, 49-68.

13. Collis, D. J. \& Montgomery, C. A. (1997). Corporate strategy: Resources and the scope of the firm. Chicago, Irwin.

14. Combs, J. G. \& Ketchen, Jr., D. J. (1999). Explaining interfirm cooperation and performance: Toward a reconciliation of predictions from the resource-based view and organizational economics. Strategic Management Journal, 20, 867-888.

15. Das, T. K. (2000). A resource-based theory of strategic alliances. Journal of Management, 26, 31-61.

16. Deephouse, D. L. (2000). Media reputation as a strategic resource: An integration of mass communication and resource-based theories. Journal of Management, 26, 1091-1112.

17. Eisenhardt, K. M. \& Schoonhoven, C. B. (1996). Resource based view of strategic alliance formation, strategic and social effects in entrepreneurial firms. Organization Science, 7, 136-150.

18. Evans, N. J. \& Jarvis, P. A. (1986). The group attitude scale: A measure of attraction to group. Small Group Behavior, 17, 203-216.

19. Farjoun, M. (1994). Beyond industry boundaries: Human expertise, diversification and resource-related industry groups. Organization Science, 5, 185-199.

20. Festinger, L. (1950). Informal social communication. Psychological Review, 57, 271-282.

21. Godfrey, P. C. \& Hill, C. W. L. (1995). The problem with unobservables in strategic management research. Strategic Management Journal, 16, 519-533.

22. Guillen, M. F. (2000). Business groups in emerging economies: A resource-based view. Academy of Management Journal, 43, 362-380.

23. Hambrick, D. C. (1995). Fragmentation and other problems CEOs have with their top management teams. California Management Review, 37, 110-127.

24. Hambrick, D. C. \& Mason, P. A. (1984). Upper echelons: The organization as a reflection of its top managers. Academy of Management Review, 9, 193-206

25. Henderson, R. \& Cockburn, I. (1994). Measuring competence? Exploring firm effects in pharmaceutical research. Strategic Management Journal, 15, 63-48.

26. Hogg, M. A. (1992). The social psychology of group cohesiveness: From attraction to social identity. New York: New York University Press.

27. Hoskisson, R. E., Eden, L., Lau, C. M., \& Wright, M. (2000). Strategy in emerging economies. Academy of Management Journal, 43, 249-267.

28. Hoskisson, R. E., Johnson, R. A., \& Moesel, D. D. (1994). Corporate divestment intensity in restructuring firms: Effects of governance, strategy and performance. Strategic Management Journal, 37, 1207-1251.

29. Hitt, M. A., Bierman, L., Shimizu, K., \& Kochar, R. (2001). Direct and moderating effects of human capital on strategy and performance in professional service firms: A resource-based perspective. Academy of Management Journal, 44, 13-28.

30. Hoopes, D. G. \& Postrel, S. (1999). Shared knowledge, "glitches," and product development performance. Strategic Management Journal, 20, 837-865.

31. Keys, B. \& Wolfe, J. (1990). The role of management games and simulations in education and research. Journal of Management, 16, 307-336.

32. Klassen, R. D. \& Whybark, D. C. (1999). The impact of environmental technologies on manufacturing performance. Academy of Management Journal, 42, 599-615.

33. Lott, A. J. \& Lott, B. E. (1965). Group cohesiveness as interpersonal attraction: A review of relationships with antecedent and consequent variables. Psychological Bulletin, 64, 259-309

34. Majumar, S. K. (1998). On the utilization of resources: Perspectives from the US telecommunications industry. Strategic Management Journal, 19, 809-831.

35. Makhija, M. (2003). Comparing the resource-based and market based views of the firm: Empirical evidence for Czech privatization. Strategic Management Journal, 24, 433.

36. Maritan, C. A. (2001). Capital investment as investing in organizational capabilities: An empirically grounded process model. Academy of Management Journal 44, 513-531. 
37. Markides, C. C. \& Williamson, P. J. (1996). Corporate diversification and organizational structure: A resource-based view. Academy of Management Journal 39, 340-367.

38. Mauri, A. J. \& Micheals, M. P. (1998). Firm and industry effects within strategic management: An empirical examination. Strategic Management Journal, 19, 211-219.

39. Mehra, A. (1996). Resource and market based determinants of performance in the U.S. banking industry. Strategic Management Journal, 17, 307-322.

40. McEvily, S. K. \& Chakravarthy, B. (2002). The persistence of knowledge-based advantage: An empirical test for product performance and technological knowledge. Strategic Management Journal, 23, 285.

41. Michalisin, M. D., Karau, S. J., \& Tangpong, C. (2004). Top management team cohesion and superior industry returns: An empirical study of the resource-based view. Group and Organization Management, 29, 129-140.

42. Michalisin, M. D., Smith, R. D., \& Kline, D. M. (1997). In search of strategic assets. International Journal of Organizational Analysis, 5, 360-387.

43. Miller, D. (2003). An asymmetry-based view of advantage: Towards an attainable sustainability. Strategic Management Journal, 24, 961-975.

44. Miller, D. \& Shamsie, J. (1996). The resource-based view of the firm in two enviroments: The Hollywood film studios from 1936 to 1965. Academy of Management Journal, 39, 519-543.

45. Mullen, B. \& Copper, C. (1994). The relation between group cohesiveness and performance: An integration. Psychological Bulletin, 115, 210-227.

46. Nees, D. B. (1983). Simulation: A complementary method for research on strategic decision-making processes. Strategic Management Journal, 4, 175-185.

47. Pennings, J. M., Lee, K., \& Witteloostuijn, A. V. (1998). Human capital, social capital, and firm dissolution. Academy of Management Journal, 41, 425-440.

48. Perry-Smith, J. E. \& Blum, T. C. (2000). Work-family human resource bundles and perceived organizational performance. Academy of Management Journal, 43, 1107-1117.

49. Peteraf, M. A. (1993). The cornerstones of competitive advantage: A resource-based view. Strategic Management Journal, 14, 179-191.

50. Pettus, M. L. (2001). The resource-based view as a developmental growth process: Evidence from the deregulated trucking industry. Academy of Management Journal, 44, 878-896.

51. Porter M. E. (1980). Competitive strategy. New York: Free Press.

52. Ray, G., Barney, J. B., \& Muhanna, W. A. (2004). Capabilities, business processes, and competitive advantage: Choosing the dependent variable in empirical tests of the resource-based view. Strategic Management Journal, 25, 23-37.

53. Reed, R. \& DeFillippi, R. J. (1990). Causal ambiguity, barriers to imitation, and sustainable competitive advantage. Academy of Management Review, 15, 88-102.

54. Richard, O. C. (2000). Racial diversity, business strategy, and firm performance: A resource-based view. Academy of Management Journal, 43, 164-177.

55. Russo, M. V. \& Fouts, P. A. (1997). A resource-based perspective on corporate environmental performance and profitability. Academy of Management Journal, 40, 534-559.

56. Schwenk, C. R. (1982). Why sacrifice rigor for relevance? A proposal for combining laboratory and field research in strategic management. Strategic Management Journal, 3,_213-225.

57. Sherer, P. D., Rogovsky, N., \& Wright, N. (1998). What drives employment relationships in taxicab organizations? Linking agency to firm capabilities and strategic opportunities. Organization Science, 9, 3448.

58. Silverman, B. S. (1999). Technological resources and the direction of corporate diversification: Toward an integration of the resource-based view and transaction cost economics. Management Science, 45, 1109-1124.

59. Sharma, S. \& Vredenburg, H. (1998). Proactive corporate environmental strategy and the development of competitively valuable organizational capabilities. Strategic Management Journal, 19, 729-753.

60. Smith J. R. \& Golden P. A. (1994). Airline: A Strategic Management Simulation. Englewood Cliffs, NJ: Prentice-Hall.

61. Smith, K. G., Smith, K. A., Olian, J. D., Sims, H. P., O’Bannon, D. P., \& Scully, J. A. (1994). Top management team demography and process: The role of social integration and communication. Administrative Science Quarterly, 39, 412-438. 
62. Tziner, A. (1982). Differential effects of group cohesiveness types: A clarifying overview. Social Behavior and Personality, 10, 227-239.

63. Wernerfelt, B. (1984). A resource based view of the firm. Strategic Management Journal, 5, 171-180.

64. Wernerfelt, B. (1989). From critical resources to corporate strategy. Journal of General Management, 14, 412.

65. Youndt, M. A., Snell, S. A., Dean, J. W. Jr., \& Lepak, D. P. (1996). Human resource management, manufacturing strategy, and firm performance. Academy of Management Journal, 39, 836-866.

Table 1: Representative RBV Studies

\begin{tabular}{|c|c|c|c|}
\hline Scholars & Level & Issue & Empirical Findings \\
\hline Farjoun, 1994 & Corporate & $\begin{array}{l}\text { Diversification } \\
\text { decisions }\end{array}$ & Resources impact decisions \\
\hline $\begin{array}{l}\text { Markides \& Williamson, 1996; Robin \& } \\
\text { Weirsema, } 1995\end{array}$ & Corporate & Portfolio relatedness & $\begin{array}{l}\text { Positively associated with } \\
\text { performance }\end{array}$ \\
\hline Bergh, 1998; Silverman, 1999 & Corporate & Restructuring & Resources impact decisions \\
\hline $\begin{array}{l}\text { Das, 2000; Eisenhardt \& Schoonhoven, 1996; } \\
\text { Combs \& Ketchen, } 1999\end{array}$ & Corporate & Strategic alliances & $\begin{array}{l}\text { Corporate resources influence } \\
\text { alliance formations }\end{array}$ \\
\hline $\begin{array}{l}\text { Collis, 1991; Guillen, 2000; Hoskisson, Eden, } \\
\text { Lau, \& Wright, 2000; Maritan, 2001; Pettus, } 2001\end{array}$ & Corporate & Managerial decisions & $\begin{array}{l}\text { Managers use RBV logic in foreign } \\
\text { direct investment choices and } \\
\text { similar decisions }\end{array}$ \\
\hline Majumar, 1998 & Business & $\begin{array}{c}\text { Resource } \\
\text { coordination }\end{array}$ & $\begin{array}{l}\text { Interaction impacts firm } \\
\text { performance }\end{array}$ \\
\hline Henderson \& Cockburn, 1994 & Business & $\begin{array}{l}\text { First mover } \\
\text { advantages }\end{array}$ & $\begin{array}{l}\text { Firm resources impact first mover } \\
\text { advantages }\end{array}$ \\
\hline Sharma \& Vredenburg, 1998 & Business & Resources evolution & $\begin{array}{l}\text { Resources evolve as firms react to } \\
\text { their environments }\end{array}$ \\
\hline Miller \& Shamsie, 1996 & Business & Competitive contexts & $\begin{array}{l}\text { Contexts affect the profit- } \\
\text { generating capacity of resources }\end{array}$ \\
\hline Berman, Down, \& Hill, 2002 & Business & Experience over time & $\begin{array}{l}\text { Impact of experience on NBA } \\
\text { basketball team performance } \\
\text { diminishes over time }\end{array}$ \\
\hline Mehra 1996 & Business & $\begin{array}{l}\text { Predictors of firm } \\
\text { performance }\end{array}$ & $\begin{array}{l}\text { Firm characteristics better } \\
\text { predictors of performance than } \\
\text { industry characteristics }\end{array}$ \\
\hline $\begin{array}{l}\text { Christmann, 2000; Klassen \& Whybark, 1999; } \\
\text { Russo \& Fouts, } 1997\end{array}$ & Business & $\begin{array}{l}\text { Environmental } \\
\text { technologies \& } \\
\text { performance }\end{array}$ & $\begin{array}{l}\text { Investments in environmental } \\
\text { technologies seem to enhance } \\
\text { environmental performance }\end{array}$ \\
\hline Ray, Barney, \& Muhanna, 2004 & Business & $\begin{array}{c}\text { Effectiveness of } \\
\text { business processes }\end{array}$ & $\begin{array}{l}\text { Customer service technologies } \\
\text { improve business processes }\end{array}$ \\
\hline $\begin{array}{l}\text { Brush \& Artz, 1999; Hitt, Bierman, Shimizu, \& } \\
\text { Kochar, 2001; Hoopes \& Postrel, 1999; Pennings, } \\
\text { Lee, \& Witteloostuijn, 1998; Perry-Smith \& } \\
\text { Blum, 2000; Richard, 2000; Sherer, Rogovski, \& } \\
\text { Wright, 1998; Youndt, Snell, Dean, \& Lepak, } \\
1996\end{array}$ & Business & $\begin{array}{c}\text { human capital \& firm } \\
\text { strategy and } \\
\text { performance }\end{array}$ & $\begin{array}{l}\text { Employee relationship } \\
\text { management, responsiveness to } \\
\text { environmental change, work- } \\
\text { family policies, and diversity } \\
\text { impact firm strategy and } \\
\text { performance }\end{array}$ \\
\hline McEvily \& Chakravarthy, 2002; Miller 2000 & Business & Knowledge & $\begin{array}{l}\text { Knowledge-based resources may } \\
\text { be strategic assets }\end{array}$ \\
\hline Carpenter, Sanders, and Gregersen, 2001 & CEO & $\begin{array}{l}\text { International } \\
\text { Experience }\end{array}$ & $\begin{array}{l}\text { CEO international experience is a } \\
\text { strategic asset }\end{array}$ \\
\hline Deephouse, 2000 & CEO & Media reputation & $\begin{array}{l}\text { Media reputation is a strategic } \\
\text { resource to banks. }\end{array}$ \\
\hline Makhija 2003 & CEO & $\begin{array}{l}\text { RBV variables versus } \\
\text { market variables }\end{array}$ & $\begin{array}{l}\text { RBV variables superior to market } \\
\text { variables in explaining share values }\end{array}$ \\
\hline
\end{tabular}


Table 2: Principal Component Analysis of Firm Performance Measures

\begin{tabular}{|c|c|c|c|c|c|c|}
\hline & \multicolumn{6}{|l|}{ Period } \\
\hline & 1 & 2 & 3 & 4 & 5 & 6 \\
\hline Barlett's Test $^{\mathrm{a}}$ & $336.98 * * *$ & $547.43 * * *$ & $420.81 * * *$ & $469.02 * * *$ & $609.39 * * *$ & $614.66 * * *$ \\
\hline Eigenvalue & 3.47 & 3.62 & 3.58 & 3.54 & 3.74 & 3.75 \\
\hline$\%$ Variance & $87 \%$ & $90 \%$ & $89 \%$ & $88 \%$ & $94 \%$ & $94 \%$ \\
\hline & & & & & & \\
\hline \multicolumn{7}{|l|}{ Loadings: } \\
\hline EPS & .94 & .95 & .94 & .92 & .94 & .94 \\
\hline ROS & .90 & .98 & .96 & .97 & .98 & .98 \\
\hline NPSM & .96 & .95 & .96 & .95 & .98 & .98 \\
\hline NPEE & .93 & .93 & .93 & .92 & .97 & .97 \\
\hline \multicolumn{7}{|l|}{ 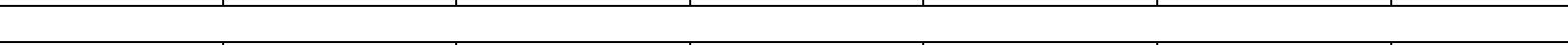 } \\
\hline & 7 & 8 & 9 & 10 & 11 & \\
\hline Barlett's Test $^{\mathrm{a}}$ & $483.78 * * *$ & $502.64 * * *$ & $485.04 * * *$ & $414.93 * * *$ & $461.32 * * *$ & \\
\hline Eigenvalue & 3.44 & 3.58 & 3.43 & 3.39 & 3.50 & \\
\hline$\%$ Variance & $86 \%$ & $90 \%$ & $86 \%$ & $85 \%$ & $88 \%$ & \\
\hline \multicolumn{7}{|l|}{ Loadings: } \\
\hline EPS & .85 & .91 & .84 & .81 & .86 & \\
\hline ROS & .96 & .97 & .96 & .96 & .95 & \\
\hline NPSM & .96 & .97 & .96 & .95 & .96 & \\
\hline NPEE & .93 & .94 & .94 & .96 & .97 & \\
\hline
\end{tabular}

Note: All firm performance measures are relative medians (firm performance relative to the median firm performance for the industry).

${ }^{a}$ Bartlett's Test of Sphericity (Chi Square Statistic)

$* * * \mathrm{p}<0.001$

Table 3: Correlations and Descriptive Statistics -- Period 11

\begin{tabular}{|l|c|c|c|c|c|c|c|c|c|}
\hline Variable & Mean & S.D. & $\mathbf{1}$ & $\mathbf{2}$ & $\mathbf{3}$ & $\mathbf{4}$ & $\mathbf{5}$ & $\mathbf{6}$ & $\mathbf{7}$ \\
\hline 1 Firm Performance & .00 & 1.00 & & & & & & & \\
\hline 2 TMT Attraction & 7.51 & .45 & $.20^{*}$ & & & & & & \\
\hline 3 Prior Performance & .00 & 1.00 & $.69^{* *}$ & .13 & & & & & \\
\hline 4 Semester & .69 & .47 & -.01 & .13 & .01 & & & & \\
\hline 5 Competitors & 9.94 & 2.23 & -.03 & .04 & -.01 & $.15^{\dagger}$ & & & \\
\hline 6 TMT Size & 4.16 & .57 & -.08 & -.02 & -.11 & -.13 & $-.24^{*}$ & & \\
\hline 7 Firm Size & 211.61 & 99.40 & $.21^{*}$ & $.16^{\dagger}$ & $.31^{* *}$ & -.01 & .02 & -.10 & \\
\hline 8 Leverage & 1.05 & 2.18 & $-.57^{* *}$ & .08 & $-.70^{* *}$ & -.13 & $.19^{*}$ & .13 & -.25 \\
\hline
\end{tabular}

$\mathrm{p}<0.10$

* $\quad \mathrm{p}<0.05$

$* * \quad \mathrm{p}<0.01$ 
Table 4: Multiple Regression Results by Period [Y = Superior Industry Returns]

\begin{tabular}{|c|c|c|c|c|c|c|}
\hline Variables & Period 1 & Period 2 & Period 3 & Period 4 & Period 5 & Period 6 \\
\hline Independent: & $\beta^{\mathrm{a}}$ & $\beta^{\mathrm{a}}$ & $\beta^{\mathrm{a}}$ & $\beta^{\mathrm{a}}$ & $\beta^{\mathrm{a}}$ & $\beta^{\mathrm{a}}$ \\
\hline -TMT Attraction & .12 & -.05 & .03 & .13 & .12 & $.38 * * *$ \\
\hline \multicolumn{7}{|l|}{ Controls: } \\
\hline -Semester & -.03 & -.01 & -.05 & .09 & -.04 & -.11 \\
\hline -Competitors & .09 & -.02 & -.03 & .02 & .02 & -.02 \\
\hline -TMT Size & .04 & -.13 & -.11 & -.03 & -.04 & -.09 \\
\hline -Firm Size & -.15 & -.13 & .09 & $-.25 * *$ & -.05 & -.07 \\
\hline -Leverage & $-.36 * *$ & $-.41 * * *$ & -.12 & -.06 & $-.33 * *$ & -.14 \\
\hline - Prior Performance & NA & .14 & $.46 * * *$ & $.60 * * *$ & $.40 * * *$ & $.53 * * *$ \\
\hline \multicolumn{7}{|l|}{ Model Statistics: } \\
\hline$\cdot \mathrm{R}^{2}$ & .16 & .28 & .27 & .46 & .41 & .50 \\
\hline -Adjusted $\mathrm{R}^{2}$ & .09 & .21 & .21 & .42 & .35 & .45 \\
\hline$\cdot \mathrm{F}$ & $2.38 *$ & $4.08 * *$ & $4.04 * *$ & $9.30 * * *$ & $7.34 * * *$ & $10.64 * * *$ \\
\hline Variables & Period 7 & Period 8 & Period 9 & Period 10 & Period 11 & \\
\hline Independent: & $\beta^{\mathrm{a}}$ & $\beta^{\mathrm{a}}$ & $\beta^{\mathrm{a}}$ & $\beta^{\mathrm{a}}$ & $\beta^{\mathrm{a}}$ & \\
\hline -TMT Attraction & $.18^{*}$ & $.18 *$ & $.22 * *$ & $.21 * *$ & $.18^{*}$ & \\
\hline \multicolumn{7}{|l|}{ Controls: } \\
\hline -Semester & $-.16^{\dagger}$ & .00 & -.10 & -.07 & -.10 & \\
\hline -Competitors & -.03 & -.02 & .00 & .05 & .05 & \\
\hline -TMT Size & -.01 & -.02 & -.01 & .04 & .01 & \\
\hline -Firm Size & .08 & -.11 & .00 & .06 & -.03 & \\
\hline -Leverage & -.04 & .08 & -.13 & -.13 & $-.25^{\dagger}$ & \\
\hline -Prior Performance & $.65 * * *$ & $.82 * * *$ & $.67 * * *$ & $.62 * * *$ & $.49 * * *$ & \\
\hline \multicolumn{7}{|l|}{ Model Statistics: } \\
\hline$\cdot \mathrm{R}^{2}$ & .53 & .63 & .64 & .59 & .49 & \\
\hline -Adjusted $\mathrm{R}^{2}$ & .49 & .60 & .61 & .55 & .45 & \\
\hline$\cdot \mathrm{F}$ & $12.18 * * *$ & $18.31 * * *$ & $19.41 * * *$ & $15.39 * * *$ & $10.40 * * *$ & \\
\hline
\end{tabular}

\footnotetext{
a Standardized regression coefficients

$\dagger \quad \mathrm{p}<0.10$

$* \quad \mathrm{p}<0.05$

$* * \quad \mathrm{p}<0.01$

$* * * \mathrm{p}<0.001$
} 
Figure 1: TMTA and Firm Performance by Period

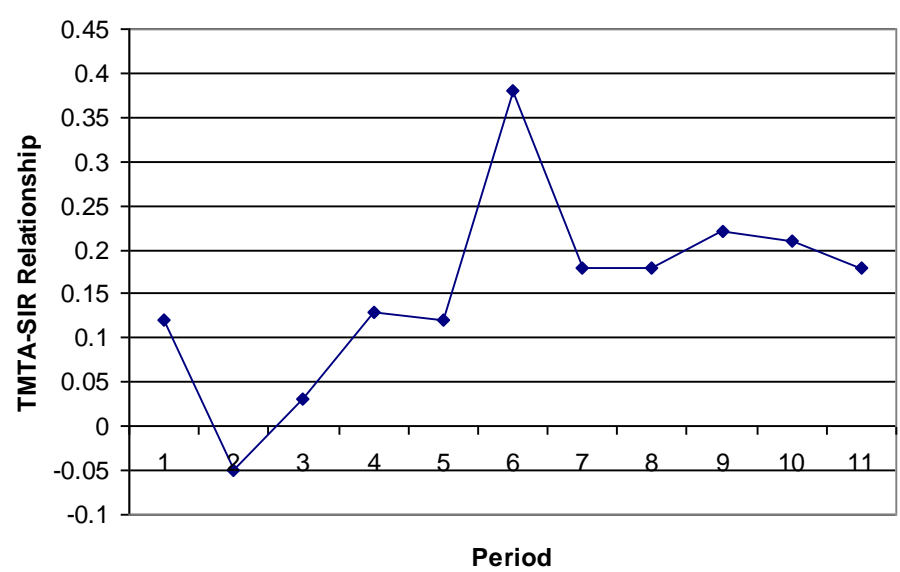

TMTA $=$ Top Management Team Attraction SIR $=$ Superior Industry Returns

Values are standardized regression coefficients. 